\title{
Genotypic characterization of ten microsatellite loci in two Brazilian free range (Caipira) chicken lines
}

\author{
Caracterização genotípica de dez loci de microssatélites em duas linhagens de galinhas caipiras \\ brasileiras
}

\author{
Mari Helen Pagani Possamai ${ }^{I}$ Jaqueline Battilana $^{\mathrm{I}}$ Ediane Paludo $^{\mathrm{I}}$ Marcos Edgar Herkenhoff $^{\mathrm{II}}$ \\ Fábio Pértille ${ }^{\mathrm{III}}$ Carlos André da Veiga Lima-Rosa ${ }^{\mathrm{IV}}$
}

\begin{abstract}
This study aimed to investigate the genetic variability of two Brazilian free range (Caipira) chickens lines using microsatellites analysis of ten loci. It was collected a total of 99 blood samples, which 49 were from Paraiso Pedrês (PP) and 50 were from Rubro Negra (RN) lines. The amplification of the DNA fragments was performed by polymerase chain reaction $(P C R)$ and the genotyping was conduct using ABI 3130 sequencer. The allele number variation was among 3 (LEI0254) to 32 (LEI0212) in the PP line, and 4 (LEI0254) to 31 (LEI0212) in the RN line. The allelic average per locus was 13.3 and 13.1 in the PP and RN lines, respectively. The average observed and the expected heterozygosity were 0.650 and 0.820 in the PP line, and 0.671 and 0.804 in the $R N$ line. All of the analyzed loci were informative $(P I C>0.5)$. These results indicate that these free-range animals have a high genetic variability, at least for the majority of the analyzed loci, and this genetic variation is higher than the commercial chickens and similar for the no-commercial birds.
\end{abstract}

Key words: (Caipira) broiler line, (Caipira) layer line, microsatellite, polymorphism.

\section{RESUMO}

Este trabalho teve como objetivo investigar a variabilidade genética de duas linhagens de galinhas caipiras brasileiras usando 10 locos de microssatélites. Noventa e nove amostras de sangue total foram coletadas, sendo 49 da linhagem Paraíso Pedrês (PP) e 50 da linhagem Rubro Negra (RN). As amplificações dos fragmentos do DNA foram realizadas pela técnica da reação em cadeia pela polimerase (PCR), e a genotipagem ocorreu em um sequenciador ABI 3130. O número de alelos variou de 3 (LEI0254) a 32 (LEI0212), na linhagem PP, e de 4 (LEI0254) a 31 (LEI0212), na linhagem RN. O número médio de alelos por loco foi de 13,3 e de 13,1 nas linhagens PP e $R N$, respectivamente. A heterozigosidade observada média e a heterozigosidade esperada média foram 0,650 e 0,820, na linhagem $P P$, e 0,671 e 0,804, na linhagem RN. Todos os locos analisados foram informativos (PIC $>0,5)$. Estes resultados indicam que estes animais caipiras têm uma grande variabilidade genética, pelo menos para a maioria dos locos analisados, e que esta variação genética é maior do que a das galinhas comerciais e semelhante à de aves não comerciais.

Palavras chave: linhagem frango caipira, linhagem poedeira caipira, microssatélites, polimorfismo.

\section{INTRODUCTION}

The chickens arrived on Brazil with the Portuguese sailors who brought exemplars of birds that came from Asia, Mediterranean and southern Europe breeds, which were left in freedom in the backyards of homes, farms and ranches (ALBINO et al., 2010). This freedom allowed the occurrence of random breeding among the breeds, originating from this blend of breeds, the birds called Brazilian free range (Caipira) chickens.

\footnotetext{
'Laboratório de Análises Genéticas da Universidade do Estado de Santa Catarina (DNA/UDESC), Centro de Ciências Agroveterinárias (CAV), Universidade do Estado de Santa Catarina (UDESC), Lages, SC, Brasil.

IDepartamento de Genética, Instituto de Biociências, Universidade Estadual Paulista "Júlio de Mesquita Filho" (UNESP), Botucatu, SP, Brasil.

IILLaboratório de Biotecnologia, Escola Superior de Agricultura "Luiz de Queiroz" (ESALQ), Universidade de São Paulo (USP), Piracicaba, SP, Brasil.

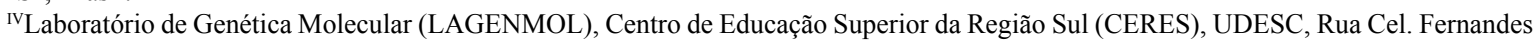
Martins, 270, Bairro Progresso, 88790-000, Laguna, SC, Brasil. E-mail: carlos.lima@udesc.br. Corresponding author. Received 01.30.14 Approved 09.30.14 Returned by the author 12.30.14 CR-2014-0132.R2
} 
These chickens are characterized by their high genetic variability (ALBINO et al., 2010) and it has been showed by few studies. LIMA-ROSA et al. (2004) investigated the polymorphism of two genes $B-F$ (genes of the immune system of the chicken) from Brazilian (blue-egg Caipira) chickens samples. CLEMENTINO et al. (2010) examined the variability of microsatellite markers in free range chickens from northeastern Brazil. FONTEQUE et al. (2014) identified the genetic variation of microsatellite loci from a population of Brazilian (blue-egg Caipira) chickens. In all of these studies a high genetic polymorphism were found.

The Brazilian free range (Caipira) chickens were let free in the backyards all over the country, where they provided a food source. However, after the Second World War, the Brazil has incorporated modern breeding poultry technology and, this way, birds with high productive skills were developed. The free range chickens, which have low productivity, have been forgotten in the backyards (ALBINO et al., 2010).

In the 80's, the consumption habits of the population changed, making people to begin to appreciate product considered "natural" or healthy. This way, the free range chickens has conquered space in the market attracting selected consumers (GESSULLI, 1999).

The demand of this type of product was increased but the free range chickens, due theirs low productivity, failed to supply this market. The way out of it was the development of the Brazilian free range (Caipira) chickens lines. These lines join the high productivity of commercial chickens with the rusticity of free range chickens (ALBINO et al., 2010). Thus, some lines have emerged to attend the Brazilian market, as the Paraíso Pedrês (PP), which is a free range (Caipira) broiler line, and the Rubro Negra $(\mathrm{RN})$, a free range (Caipira) layer line.

These two lines were developed by selecting features of pure chickens breeds inside the free range chickens variety in the Aves do Paraíso farm (Itatiba - São Paulo - Brazil; FAZENDA AVES DO PARAÍSO LTDA.). When free range roosters or hens possessed desirable traits of pure breeds, they were-selected, crossbred and the features were refined, resulting in commercial lines from Brazilian free range (Caipira) chickens.

Microsatellites, which are repeated tandem sequences between 1 to 6 nucleotides, are good markers to study the genetic variability. They are numerous and commonly marker used in nuclear DNA analyzes. The microsatellites have a co- dominant inheritance, being easily to identify and polymorphic (KAYA \& YILDIZ, 2008). This study aimed to evaluate with microsatellites markers the genetic variability of these two free range chicken lines (broiler and layer) and compare the results with others chickens (commercial or no-commercial).

\section{MATERIAL AND METHODS}

The 49 Paraíso Pedrês (PP) and 50 Rubro Negra (RN) chicks were acquired from Aves do Paraíso farm (Itatiba - São Paulo - Brazil) with one day old. The PP line reaches slaughter weight $(2.8 \mathrm{~kg})$ at 9 to 10 weeks of age, with food conversion rate of $2.3(\mathrm{~kg}$ feed $/ \mathrm{kg}$ meat) and daily weight gain of $0.04295 \mathrm{Kg} / \mathrm{day}$. The RN line can produce 280 eggs a year (FAZENDA AVES DO PARAÍSO LTDA.).

The chicks were raised until 60 days old and then the blood samples were collected. It was used peripheral blood samples collected with $0.5 \%$ EDTA from all animals. The total DNA was extracted from erythrocytes through the protocol established by SAMBROOK et al. (1989).

The amplification of microsatellites loci was performed using the Polymerase Chain Reaction (PCR), with primers labeled with fluorophores: LEI0192, LEIO194, LEI0212, LEI0214, LEI0217, LEI0221, LEI0248, LEI0254 (described by MCCONNELL et al., 1999), and MCW0081, MCW0183 (described by CROOIJMANS et al., 1997).

The reagents used in PCR reactions were 10X Buffer (100mM Tris-HCl, 500mM KCl, pH 8.3), $\mathrm{MgCl}_{2}$ (10-40mM; that is depends of the microsatellite loci; more information see MCCONNELL et al., 1999 or CROOIJMANS et al., 1997), $1.25 \mathrm{mM}$ dNTP mix (dATP, dCTP, dGTP, dTTP), $1 \mathrm{mM}$ of each primer, forward and reverse (forward labeled with fluorescence), 0.5 unit of Taq polymerase, $\mathrm{H}_{2} \mathrm{O}$ to complete the final volume of $25 \mathrm{~mL}$, and DNA (50ng). The reaction conditions were: 2 minutes at $96^{\circ} \mathrm{C}, 35$ cycles of 1 minute at $96^{\circ} \mathrm{C}, 30$ seconds to 1 minute at $48-58^{\circ} \mathrm{C}$ (depending of the primer sets; more information see MCCONNELL et al., 1999 or CROOIJMANS et al., 1997), 30 seconds at $72^{\circ} \mathrm{C}$ and 5 minutes of final extension at $72^{\circ} \mathrm{C}$.

The amplified products were submitted to an electrophoresis on automated genetic analyzer, ABI 3130 DNA Genetic Analyzer, and subsequently genotyped in the Gene Mapper ${ }^{\circledR}$ software version 3.2.1 (Applied Biosystems, Foster City, USA).

The gene frequencies were obtained by manually counting. The allele frequencies, observed 
and expected heterozygosity, and the suit to the Hardy-Weinberg equilibrium were derived from Arlequin $^{\circledR}$ software version 3.5 (EXCOFFIER \& LISCHER, 2010). The Polymorphic Information Content (PIC) was estimated in a Cervus ${ }^{\circledR}$ software, version 3.0 (KALINOWSKI et al., 2007).

\section{RESULTS AND DISCUSSION}

The data for the ten polymorphic microsatellite loci analyzed in these two Brazilian free range (Caipira) chickens lines are described in table 1. A total of 133 and 131 alleles were detected in the Paraíso Pedrês (PP) and Rubro Negra (RN) lines, respectively. The number of alleles per locus ranged from 3 (LEI0254) to 32 (LEI0212) in the PP line, and 4 (LEI0254) to 31 (LEI0212) in RN line, with an average of $13.3(\mathrm{PP})$ and $13.1(\mathrm{RN})$ alleles per loci.

Most of the microsatellite markers used in this study was polymorphic. The number of alleles per locus according with the lowest number of alleles suggested by BARKER (1994) in both studied populations, which should be at least four alleles per loci to reduce the effect on the standard error. In the present study, only the marker LEI0254 in PP line presented low number of allele per locus, which was three. This locus was mapped on $\mathrm{Z}$ chromosome (MCCONNELL et al., 1999), and lies in a region of reduced genetic variability. SUNDSTRÖM et al. (2004) investigated the diversity of the $\mathrm{Z}$ chromosome and observed three- to fourfold reduction on the $Z$ than on the autosomes.

The average number of alleles is high (13.3 in PP and 13.1 in RN). CLEMENTINO et al. (2010) and FONTEQUE et al. (2014) found an average number of 9.6 and 12.4 alleles per locus, respectively, in studies with microsatellites in free range chickens from Brazil. Lower values than the results found in this study were also described by AL-QAMASHOUI et al. (2014), BAO et al. (2009); HASSEN et al. (2009), MOHAMMADABADI et al. (2010), MWACHARO et al. (2013), LEROY et

Table 1 - Values to several parameters of genetic polymorphism from 10 microsatellite loci analyzed in samples of two Brazilian free range (Caipira) chickens lines.

\begin{tabular}{|c|c|c|c|c|c|c|c|c|}
\hline Loci & $\mathrm{N}_{\mathrm{a}}{ }^{1}$ & $\mathrm{~T}^{2}(\mathrm{pb})$ & $\mathrm{Ho}^{3}$ & $\mathrm{He}^{4}$ & Value of $p^{5}$ & s.d. ${ }^{6}$ & $\mathrm{Ap}^{7}$ & $\mathrm{PIC}^{8}$ \\
\hline LEI0192 & 16 & $246-342$ & 0.738 & 0.852 & 0.001 & 0.000 & 3 & 0.601 \\
\hline LEI0194 & 8 & $117-163$ & 0.405 & 0.791 & 0.000 & 0.000 & 1 & 0.761 \\
\hline LEI0212 & 32 & $338-470$ & 0.857 & 0.948 & 0.202 & 0.000 & 11 & 0.836 \\
\hline LEI0214 & 18 & $133-311$ & 0.333 & 0.867 & 0.000 & 0.000 & 5 & 0.904 \\
\hline LEI0217 & 17 & $182-276$ & 0.905 & 0.925 & 0.118 & 0.000 & 2 & 0.912 \\
\hline LEI0221 & 14 & $180-228$ & 0.976 & 0.918 & 0.970 & 0.000 & 0 & 0.801 \\
\hline LEI0248 & 9 & $222-262$ & 0.810 & 0.825 & 0.334 & 0.000 & 2 & 0.937 \\
\hline LEI0254 & 3 & $81-85$ & 0.000 & 0.660 & 0.000 & 0.000 & 0 & 0.767 \\
\hline$M C W 0081$ & 6 & $97-127$ & 0.833 & 0.627 & 0.052 & 0.002 & 1 & 0.851 \\
\hline$M C W 0183$ & 10 & $258-304$ & 0.643 & 0.791 & 0.008 & 0.000 & 4 & 0.571 \\
\hline Mean & 13.3 & - & 0.650 & 0.820 & - & - & 2.9 & 0.794 \\
\hline LEI0192 & 15 & $232-342$ & 0.800 & 0.853 & 0.286 & 0.000 & 2 & 0.508 \\
\hline LEIO194 & 8 & $121-163$ & 0.640 & 0.770 & 0.101 & 0.000 & 1 & 0.769 \\
\hline LEI0212 & 31 & $352-468$ & 0.880 & 0.956 & 0.010 & 0.000 & 10 & 0.835 \\
\hline LEI0214 & 17 & $125-311$ & 0.260 & 0.834 & 0.000 & 0.000 & 4 & 0.876 \\
\hline LEI0217 & 17 & $174-250$ & 0.860 & 0.928 & 0.004 & 0.000 & 2 & 0.907 \\
\hline LEI0221 & 14 & $180-228$ & 0.880 & 0.874 & 0.858 & 0.000 & 0 & 0.719 \\
\hline LEI0248 & 9 & $214-254$ & 0.640 & 0.694 & 0.362 & 0.000 & 2 & 0.951 \\
\hline LEIO254 & 4 & $81-87$ & -9 & - & - & - & 1 & 0.763 \\
\hline$M C W 0081$ & 6 & $97-127$ & 0.380 & 0.535 & 0.001 & 0.000 & 1 & 0.783 \\
\hline$M C W 0183$ & 10 & $258-310$ & 0.700 & 0.794 & 0.000 & 0.000 & 4 & 0.539 \\
\hline Mean & 13.1 & - & 0.671 & 0.804 & - & - & 2.7 & 0.765 \\
\hline
\end{tabular}

${ }^{1}$ Allele numbers per locus; ${ }^{2}$ Allele size in base pairs; ${ }^{3}$ Frequency of observed heterozygosity, ${ }^{4}$ Frequency of expected heterozygosity; ${ }^{5}$ HardyWeinberg equilibrium in the population studied, locus in equilibrium $(\mathrm{P}>0.05){ }^{6} \mathrm{Standard}$ deviation; ${ }^{7}$ Private allele: ${ }^{8}$ Polymorphic Information Content: ${ }^{9}$ All sample were female, so hemizygous for this locus, thus it was not considered in this analysis. 
al. (2012), PHAM et al. (2013) and ZHANG et al. (2002) in studies with native chickens in Oman, China, Ethiopia, Iran, East African, North, West and Central Africa, Vietnam and China, respectively. The average number of alleles per locus in commercial poultry breeds or lines has been determined around 1.3 to 8.4 (VANHALA et al., 1998; KYSER et al., 2000; ZHANG et al., 2002; HILLEL et al., 2003; TADANO et al., 2007; BERTHOULY et al., 2008; ROSÁRIO et al., 2009; CHATTERJEE et al., 2010; TADANO et al., 2012; WILKINSON et al., 2012). Normally, it is expected that the genetic variability of commercial chickens lines had been reduced because they are selected for quantitative traits (HILLEL et al., 2003). However the average number of alleles to $\mathrm{PP}$ and $\mathrm{RN}$ lines, especially when compared to commercial birds, indicates that there were no lost in the genetic variability in the raise of these lines, originally found in their free range chickens ancestors. One possible account for it can be the genetic background. One relatively large effective population size of the grandparental of these lines with internal genetic subdivision may be reflected by the degree of polymorphism demonstrated by the $\mathrm{PP}$ and $\mathrm{RN}$ lines. Some management practices, like restricted gene flow between populations within lines, can produce genetic heterogeneity amongst flocks within breeds or lines, creating divisions of the breeds or lines: the genetic subpopulations (ROSENBERG et al. 2001; WILKINSON et al., 2012). These genetic subpopulations can have your gene pool with, occasionally, different alleles, it being able to generate high number of alleles in the population, like seen in this study.

A total of $29(21.8 \%)$ and $27(20.6 \%)$ private alleles were detected, in PP and $\mathrm{RN}$ lines, respectively. A large number of private alleles in specific microsatellites locus provide a high interest for use in genetic studies of animals. First, because it characterizes or distinguishes one specific breed or line, and second, private alleles can measure the gene flow between populations (SLATKIN \& BARTON, 1989; KALINOWSKI, 2004). The bigger the gene flow between populations the lower the number of private alleles. Nevertheless, there was no fixed locus in these populations.

The expected heterozygosity (He) was higher than the observed (Ho) in the two populations. The Ho average was 0.650 and 0.671 in PP and RN, respectively, while $\mathrm{He}$ average to $\mathrm{PP}$ was 0.820 , and to RN was 0.804 . These values are similar with those of other native chickens of China (BAO et al., 2009), India (RAJKUMAR et al., 2008), Oman
(AL-QAMASHOUI et al., 2014) and Thailand (AKABOOT et al., 2012). Probably, the selection for economic traits caused the Ho values showed in this study. Breeds and commercial lines of chickens are often raise with a rigorous genetically selection looking for traits that are desirable, which consequently can lead a decrease in the level of heterozygosity (TADANO et al., 2008). Moreover, the genetic subdivisions into the line, as mentioned above, can produce high genetic variability in the line population, but it can also reduce the polymorphism within the line subpopulations (WILKINSON et al., 2012), since one restricted gene flow tend to increase the inbreeding within the subpopulations. It can reflect in higher He (high genetic variability in the population) than Ho (low genetic variability within the subpopulations can lead to increased homozygous).

The Ho values are higher as some commercial populations (ROSÁRIO et al., 2009; CHATTERJEE et al., 2010; TADANO et al., 2012). However, in the commercial chickens the Ho values were often lower than that in the present study. These values ranged from 0.000 (high inbred lines) to 0.610 (VANHALA et al., 1998; ZHOU \& LAMONT, 1999; GRANEVITZE et al., 2007; BERTHOULY et al., 2009; ZANETTI et al., 2010; WILKINSON et al., 2012). Thus, the heterozygosity found in these Brazilian free range (Caipira) chickens, however is lower than the He, which can be considered high.

The Ho per locus showed the high degree of polymorphism in both studied lines, with more than 0.5 in $73.7 \%$ of loci. In particular, the markers LEI0212, LEI0217 and LEI0221 showed results in both free range chickens lines, suggesting the usefulness of these markers for this kind of study.

The populations presented low or none value to locus LEI0254: 4 alleles to RN and 3 to PP, and no individual heterozygous. Part of this can be because this marker is located in $\mathrm{Z}$ chromosome (as mentioned above, the $\mathrm{Z}$ presents reduced genetic variation). Moreover, for $\mathrm{RN}$ line all sample were female, showing hemizygous for this locus. In the PP line $55 \%$ of individuals were female and the rest $(45 \%)$ were homozygous male. It could be explained by some type of directed breeding, where only homozygous lines for a particular locus with specific production feature were crossed, and their products (chicks) were set mixed for sale. Then, this microsatellite could be in linkage disequilibrium with this locus. STEPHAN et al. (2006) asserted that when two loci are in linkage disequilibrium, and one is undergoing directional selection and the 
other is a neutral locus, it has strong effects on allele frequencies at the neutral locus due the selection of the locus has been selected.

In the two populations were observed deviations from Hardy-Weinberg Equilibrium (HWE). The number of loci that deviated significantly $(\mathrm{P}<0.05)$ from HWE were five $(50 \%)$ in PP, and five $(55.5 \%$; the loci LEIO254 was not considered in this analysis to $\mathrm{RN}$ sample - see Table 1) in RN lines. In the analyzed populations, this deviation was probably caused by the selection and directed mating, which contributed in the raising of these lines. However, the presence of null alleles (although no homozygous null individuals were found in this study) or the sample size could be also causing it (VANHALA et al., 1998; WEI et al., 2013).

The average value of Polymorphic Information Content (PIC) for PP was 0.794 , and 0.765 to RN lines. The PIC, as described by BOTSTEIN et al. (1980), is an indicator of marker quality in genetic studies. According to classification of these authors, markers with values above 0.5 indicate that a high genetic information can be provided by the locus. In this study, all markers had PIC higher than 0.5 , showing high level of polymorphism in all the analyzed microsatellite loci. The PIC values were similar as reported by CLEMENTINO et al. (2010) in one study with Brazilian free-range chickens, which had used six of the same markers used in this research. Likewise, FONTEQUE et al. (2014) found the PIC values similar of these, using, among others, the same microsatellites loci of this research in Brazilian (blue-egg Caipira) chickens.

In the present study, the lines demonstrate high value for average number of alleles, $\mathrm{He}$ and PIC and considerable value for Ho. And, despite investigating two commercial lines, the research highlight that these birds maintained high polymorphism traits of their native ancestors, it can be seen average number of alleles and Ho were higher than the commercial breeds or lines and similar for the no-commercial chickens. It was also observed high variability in the composition of the two lines, because each bird presented a unique genotype combination of all alleles (data not shown), resulting in many specific genotypes per locus per line. Therefore, it was considered that these two lines genetically distinct, characterized them as lines derived from selected crossings, but at the same time, maintained the genetic variability.

\section{CONCLUSION}

The two Brazilian free range (Caipira) chickens lines, Paraíso Pedrês and Rubro Negra, have a high genetic variability, at least for the majority of the analyzed loci, and this genetic variation was higher than observed in typical commercial lines of chickens and similar to that observed in non-commercial birds. The results also indicated that it can be selected lines or breeds for economic traits maintaining the polymorphism of the populations. The preservation of genetic variation in the populations is very important to animal breeding because it is the source for the initiation or continuation of genetic improvement programs.

\section{ETHICS COMMITTEE AND BIOSAFETY}

The project was approved by the University Ethics Committee under protocol number 1.28.09/CETEA/UDESC

\section{REFERENCES}

AKABOOT, P. et al. Genetic characterization of Red Junglefowl (Gallus gallus), Thai indigenous chicken (Gallus domesticus), and two commercial lines using selective functional genes compared to microsatellite markers. Genetics and Molecular Research, v.11, n.3, p.1881-1890, 2012. Available from: <http://www.funpecrp. com.br/gmr/year2012/vol11-3/pdf/gmr1665.pdf>. Accessed: Jan. 03, 2014. doi: 10.4238/2012.July.19.7.

ALBINO, L.F.T. et al. Criação de frango e galinha caipira: avicultura alternativa. 3.ed. Viçosa: Aprenda Fácil, 2010. 208p.

AL-QAMASHOUI, B. et al. Assessment of genetic diversity and conservation priority of Omani local chickens using microsatellite markers. Tropical Animal Health and Production, published online: Mar. 04, 2014. Available from: <http://link.springer.com/ article/10.1007/s11250-014-0558-9>. Accessed: Apr. 21, 2014. doi: 10.1007/s11250-014-0558-9.

BAO, W.B. Genetic diversity and relationship between genetic distance and geographical distance in 14 Chinese indigenous chicken breeds and red jungle fowl. Czech Journal of Animal Science, v.54, p.74-83, 2009. Available from: <http://www. agriculturejournals.cz/publicFiles/03933.pdf $>$. Accessed: Apr. 15, 2014

BARKER, J.S.F. A global protocol for determining genetic distance among domestic livestock breeds. In: WORLD CONGRESS GENETICS APPLIED TO LIVESTOCK PRODUTION, 5., 1994, Guelph, Ontario, Canada. Proceedings... Guelph: Univ. Guelph, 1994. p.501-508.

BERTHOULY, C. et al. Using molecular markers and multivariate methods to study the genetic diversity of local European and Asian chicken breeds. Animal Genetics, v.39, p.121-129, 2008. Available from: <http://onlinelibrary.wiley.com/doi/10.1111/ j.1365-2052.2008.01703.x/pdf>. Accessed: Jan. 03, 2014 doi:10.1111/j.1365-2052.2008.01703.x.

BERTHOULY, C. et al. Genetic analysis of local Vietnamese chickens provides evidence of gene flow from wild to domestic populations. BMC Genetics, v.10, p.1, 2009. Available from: $<$ http://www.biomedcentral.com/1471-2156/10/1>. Accessed: Jan. 03, 2014. doi:10.1186/1471-2156-10-1.

Ciência Rural, v.45, n.5, mai, 2015. 
BOTSTEIN, D. et al. Construction of a genetic linkage map in man using fragment length polymorphisms. American Journal of Human Genetics, v.32, p.314-331, 1980. Available from: $<$ http://www.ncbi.nlm.nih.gov/pmc/articles/PMC1686077/pdf/ ajhg00189-0020.pdf>. Accessed: Jan. 21, 2014.

CHATTERJEE, R.N. et al. Assessment of genetic relatedness of crossbred chicken populations using microsatellite markers. Biochemical Genetics, v.48, p.727-736, 2010. Available from: $<$ http://link.springer.com/article/10.1007/s10528-010-9355-y >. Accessed: Jan. 03, 2014. doi: 10.1007/s10528-010-9355-y.

CLEMENTINO, C.S. et al. Microsatellite DNA loci for population studies in Brazilian chicken ecotypes. International Journal of Poultry Science, v.9, n.12, p.1100-1106, 2010. Available from: $<$ http://scialert.net/qredirect.php?doi=ijps.2010.1100.1106\&linkid $=$ pdf $>$. Accessed: Jan. 21, 2014. doi: 10.3923/ijps.2010.1100.1106.

CROOIJMANS, R.P. et al. New microsatellite marker in chicken optimized for automated fluorescent genotyping. Animal Genetics, v.28, n.6, p.427-437, 1997. Available from: <http://onlinelibrary. wiley.com/doi/10.1111/j.1365-2052.1997.00205.x/pdf >. Accessed: Jan. 03, 2014. doi: 10.1111/j.1365-2052.1997.00205.x.

EXCOFFIER, L.; LISHER, H.E.L. Arlequim suite ver 3.5: a new series of programs to perform population genetics analyses under Linux and Windows. Molecular Ecology Resouces, v.10, p.564-567, 2010. Available from: $<$ http://onlinelibrary.wiley.com/ doi/10.1111/j.1755-0998.2010.02847.x/pdf>. Accessed: Jan. 21, 2014. doi: 10.1111/j.1755-0998.2010.02847.x.

FAZENDA AVES DO PARAÍSO LTDA. Accessed: Mar. 07, 2014. Online. Available from: <http://www.frangocaipira.com.br/index. html>.

FONTEQUE, G.V. et al. Genetic polymorphism of fifteen microsatellite loci in Brazilian (blue-egg Caipira) chickens. Pesquisa Veterinária Brasileira, v.34, p.98-102, 2014. Available from: $<$ http://www.scielo.br/pdf/pvb/v34n1/16.pdf $>$. Accessed: Mar. 08, 2014. doi: 10.1590/S0100-736X2014000100016.

GESSULLI, O.P. Avicultura alternativa. Porto Feliz: OPG, 1999. $218 \mathrm{p}$.

GRANEVITZE, Z. et al. Genetic diversity within chicken populations from different continents and management histories. Animal Genetics, v.38, v.6, p.576-583, 2007. Available from: <http://onlinelibrary.wiley.com/doi/10.1111/ j.1365-2052.2007.01650.x/pdf>. Accessed: Jan. 03, 2014. doi: 10.1111/j.1365-2052.2007.01650.x.

HASSEN, H. et al. Study on the genetic diversity of native chickens northwest Ethiopia using microsatellite marker. African Journal of Biotechnology, v.8, n.7, p.1347-1353, 2009. Available from: $<$ http://www.ajol.info/index.php/ajb/article/view/60118/48375>. Accessed: Jan. 03, 2014. doi: 10.4314/ajb.v8i7.60118.

HILLEL, J. et al. Biodiversity of 52 chicken populations assessed by microsatellite typing of DNA pools. Genetics Selection Evolution, v.35, p.533-557, 2003. Available from: <http://www. biomedcentral.com/content/pdf/1297-9686-35-6-533.pdf $>$. Accessed: Mar. 08, 2014. doi: 10.1051/gse:2003038.

KALINOWSKI, S.T. Counting alleles with rarefaction: Private alleles and hierarchical sampling designs. Conservation Genetics, v.5, p.539-543, 2004. Available from: <http://www.
montana.edu/kalinowski/KalinowskiReprints/2004_Rarefaction ConservationGenetics.pdf $>$. Accessed: Mar. 01, 2014. doi: 10.1023/B:COGE.0000041021.91777.1a.

KALINOWSKI, S.T. et al. Revising how the computer program CERVUS accommodates genotyping error increases success in paternity assignment. Molecular Ecology, v.16, p.1099-1006, 2007. Available from: $<$ http://onlinelibrary.wiley.com/doi/10.1111/ j.1365-294X.2007.03089.x/pdf>. Accessed: Jan. 03, 2014. doi: 10.1111/j.1365-294X.2007.03089.X.

KAYA, M.; YILDIZ, M.A. Genetic diversity among Turkish native chickens, Denizli and Gerze, estimated by microsatellite markers. Biochemical Genetics, v.46, p.480-491, 2008. Available from: <http://www.ncbi.nlm.nih.gov/pmc/articles/ PMC2480610/?report=reader>. Accessed: Jan. 03, 2014. doi: 10.1007/s10528-008-9164-8.

KYSER, M.G. et al. Microsatellite polymorphism between and within broiler populations. Poultry Science, v.79, p.626-628, 2000. Available from: <http://ps.oxfordjournals.org/content/79/5/626. full.pdf $>$. Accessed: Apr. 21, 2014. doi: 10.1093/ps/79.5.626.

LEROY, G. et al. Gene diversity, agroecological structure and introgression patterns among village chicken populations across North, West and Central Africa. BMC Genetics, v.13, p.34, 2012. Available from: <http://www.biomedcentral.com/ content/pdf/1471-2156-13-34.pdf $>$. Accessed: Jan. 03, 2014. doi:10.1186/1471-2156-13-34.

LIMA-ROSA, C.A.V. et al. B-F DNA sequence variability in Brazilian (blue-egg Caipira) chickens. Animal Genetics, v.35, n.4, p.278-284, 2004. Available from: <http://onlinelibrary.wiley.com/ doi/10.1111/j.1365-2052.2004.01160.x/pdf>. Accessed: Jan. 21, 2014. doi: 10.1111/j.1365-2052.2004.01160.x.

McCONNELL, S.K.J. et al. The isolation and mapping of 19 tetranucleotide microsatellite markers in the chicken. Animal Genetics, v.30, p.183-189, 1999. Available from: <http:// onlinelibrary.wiley.com/doi/10.1046/j.1365-2052.1999.00454.x/ pdf>. Accessed: Jan. 03, 2014. doi: 10.1046/j.13652052.1999.00454.x

MOHAMMADABADI, M.R. et al. Genetic variability in three native Iranian chicken populations of the Khorasan province based on microsatellite markers. Genetika, v.46, n.4, p.572-576, 2010. Available from: <http://link.springer.com/article/10.1134\% 2FS1022795410040198>. Accessed: Jan. 03, 2014. doi: 10.1134/ S1022795410040198.

MWACHARO, J.M. et al. Reconstructing the origin and dispersal patterns of village chickens across East Africa: insights from autosomal markers. Molecular Ecology, v.22, p.2683-2697, 2013. Available from: <http://onlinelibrary.wiley.com/doi/10.1111/ mec.12294/pdf>. Accessed: Jan. 03, 2014. doi: 10.1111/mec.12294.

PHAM, M.H. et al. Genetic diversity of Vietnamese domestic chicken populations as decision-making support for conservation strategies. Animal Genetics, v.44, p.509-521, 2013. Available from: <http://onlinelibrary.wiley.com/doi/10.1111/age.12045/pdf>. Accessed: Jan. 03, 2014. doi: 10.1111/age.12045.

RAJKUMAR, U. et al. Genomic heterogeneity of chicken populations in India. Australasian Journal of Animal Sciences, v.21, p.1710-1720, 2008. Available from: <http://www.ajas.info/ editor/manuscript/upload/21-238.pdf $>$. Accessed: Jan. 21, 2014. 
ROSÁRIO, M.F. et al. Genotypic characterization of microsatellite markers in broiler and layer selected chicken lines and their reciprocal F1s. Scientia Agricola, v.66, p.150-158, 2009. Available from: <http://www.scielo.br/pdf/sa/v66n2/02.pdf $>$. Accessed: Apr. 08, 2014. doi: 10.1590/S0103-90162009000200002.

ROSENBERG, N.A. et al. Empirical evaluation of genetic clustering methods using multilocus genotypes from 20 chicken breeds. Genetics, v.159, p.699-713, 2001. Available from: <http:// www.genetics.org/content/159/2/699.full.pdf $>$. Accessed: Apr. 08, 2014.

SAMBROOK, J. et al. Molecular cloning: a laboratory manual. 2.ed. New York: Cold Spring Harbor Laboratory, 1989. 956p.

SLATKIN, M.; BARTON N.H. A comparison of three indirect methods for estimating average levels of gene flow. Evolution v.43, p.1349-1368, 1989. Available from: <http://onlinelibrary. wiley.com/doi/10.1046/j.1365-294x.1999.00730.x/pdf> Accessed: Apr. 13, 2014. doi/10.1046/j.1365-294x.1999.00730.x.

STEPHAN, W. et al. The hitchhiking effect on linkage disequilibrium between linked neutral loci. Genetics, v.172, p.2647-2663, 2006. Available from: <http://www.genetics.org/ content/172/4/2647.full.pdf $>$. Accessed: Apr. 08, 2014. doi: 10.1534/genetics.105.050179.

SUNDSTRÖM, H. et al. Reduced variation on the chicken Z chromosome. Genetics, v.167, p.377-385, 2004. Available from: $<$ http://www.genetics.org/content/167/1/377.full.pdf>. Accessed: Apr. 18, 2014. doi: 10.1534/genetics.167.1.377.

TADANO, R. et al. Assessing genetic diversity and population structure for commercial chicken lines based on forty microsatellite analyses. Poultry Science, v.86, p.2301-2308, 2007. Available from: <http://ps.fass.org/content/86/11/2301.full.pdf $>$. Accessed: Jan. 03, 2014. doi:10.3382/ps.2007-00233.

TADANO, R. et al. High genetic divergence in miniature breeds of Japanese native chickens compared to Red Junglefowl, as revealed by microsatellite analysis. Animal Genetics, v.39, p.71-78, 2008 Available from: $<$ http://onlinelibrary.wiley.com/doi/10.1111/ j.1365-2052.2007.01690.x/pdf $>$. Accessed: Jan. 03, 2014. doi: 10.1111/j.1365-2052.2007.01690.x.
TADANO, R. et al. Analysis of genetic divergence between closely related lines of chickens. Poultry Science, v.91, p.327-333, 2012. Available from: <http://ps.fass.org/content/91/2/327.full.pdf $>$. Accessed: Jan. 03, 2014. doi: 10.3382/ps.2011-01879.

VANHALA, T. et al. Evaluation of genetic variability and genetic distances between eight chicken lines using microsatellite markers. Poultry Science, v.77, p.783-790, 1998. Available from: <http:// www.sciencedirect.com/science/article/pii/S1002007109002627>. Accessed: Apr. 03, 2014. doi: 10.1016/j.pnsc.2009.06.008.

WEI, L. et al. Genetic diversity of four protected indigenous chicken breeds in China using microsatellite markers. South African Journal of Animal Science, v.43, p.464-472, 2013. Available from: <http://www.scielo.org.za/pdf/sajas/v43n4/03. pdf>. Accessed: Apr. 21, 2014. doi: 10.4314/sajas.v43i4.3.

WILKINSON, S. et al. Characterization of the genetic diversity, structure and admixture of British chicken breeds. Animal Genetics, v.43, n.5, p.552-563, 2012. Available from: <http:// onlinelibrary.wiley.com/doi/10.1111/j.1365-2052.2011.02296.x/ pdf $>$. Accessed: Jan. 21, 2014. doi: 10.1111/j.13652052.2011.02296.x

ZANETTI, E. et al. Genetic characterization of local Italian breeds of chickens undergoing in situ conservation. Poultry Science, v.89, p.420-427, 2010. Available from: <http://ps.fass.org/ content/89/3/420.full.pdf $>$. Accessed: Jan. 03, 2014. doi: 10.3382/ ps.2009-00324.

ZHANG, X. et al. Genetic diversity of Chinese native chicken breeds based on protein polymorphism, randomly amplified polymorphic DNA, and microsatellite polymorphism. Poultry Science, v.81, p.1463-1472, 2002. Available from: <http:// ps.oxfordjournals.org/content/81/10/1463.full.pdf $>$. Accessed: Apr. 08, 2014. doi: 10.1093/ps/81.10.1463.

ZHOU, H.; LAMONT, S.J. Genetic characterization of biodiversity in highly inbred chicken lines by microsatellite markers. Animal Genetics, v.30, p. 256-264, 1999. Available from: <http:// onlinelibrary.wiley.com/doi/10.1046/j.1365-2052.1999.00505.x/ pdf>. Accessed: Apr. 08,2014. doi: 10/1046/j.13652052.1999.00505.x. 